\title{
Hypophysitis (Including IgG4 and Immunotherapy)
}

\author{
Anna Angelousi ${ }^{a} \quad$ Krystallenia Alexandraki $^{b}$ Marina Tsoli ${ }^{b} \quad$ Gregory Kaltsas $^{b}$ \\ Eva Kassib, c
}

${ }^{a}$ First Department of Internal Medicine, Laiko University Hospital, Medical School, National and Kapodistrian University of Athens, Athens, Greece; ${ }^{b}$ First Department of Propaedeutic Internal Medicine, Laiko University Hospital, National and Kapodistrian University of Athens, Athens, Greece; 'Department of Biological Chemistry, Medical School, National and Kapodistrian University of Athens, Athens, Greece

\section{Keywords}

Hypophysitis · IgG4 · Immune checkpoint inhibitors ·

Hypopituitarism

\begin{abstract}
Hypophysitis is characterized by inflammation of the pituitary gland that can be primary $(\mathrm{PH})$ or secondary $(\mathrm{SH})$ to other diseases or following drug administration. It may also be classified according to anatomical and histopathological criteria, leading to variable degrees of hypopituitarism and/or compressive symptoms to nearby structures. There has recently been an increase in the number of hypophysitis cases, raising the interest on the spectrum of its pathogenesis, clinical, biochemical/endocrinological, and imaging features. However, the use of conventional biomarkers, including currently utilized pituitary autoantibodies, has relatively limited diagnostic accuracy. Lymphocytic hypophysitis (LH) is the commonest cause of $\mathrm{PH}$, whereas IgG4-related hypophysitis is increasingly being recognized. Histiocytosis and granulomatous diseases are the most frequent causes of $\mathrm{SH}$, although infections and lymphoma have also been reported. The increasing use of immune checkpoint inhibitors in oncology is associated with a high incidence of hypophysitis, providing further understanding of its pathogenesis. Hy-
\end{abstract}

pophysitis can occur silently and be easily missed, potentially leading to substantial morbidity or mortality due to adrenal insufficiency, requiring a high index of clinical suspicion and timely initiation of appropriate treatment. In most cases of LH or drug-induced hypophysitis, active surveillance along with replacement of established hormonal deficiencies is needed. In the presence of compressive and/or evolving symptoms, treatment with glucocorticoids either alone or in combination with other immunosuppressive agents can be used. Surgical decompression is reserved for nonresponsive cases with threatened vital structures. Timely diagnosis and intervention are important to minimize disease-related morbidity and mortality. We aimed to review current concepts and recent developments in the pathogenesis, diagnosis, and management of hypophysitis.

(c) 2020 S. Karger AG, Basel

\section{Introduction}

Hypophysitis is a heterogenous condition that develops secondary to chronic or acute inflammation of the pituitary, resulting to varying degrees in hypopituitarism and/or symptoms/signs related to sella compression [1, 2]. Hypophysitis is traditionally classified using anatomi- karger@karger.com

(c) 2020 S. Karger AG, Basel

www.karger.com/nen

Karger!
Assistant Prof. Anna Angelousi, MD, PhD

First Department of Internal Medicine, Unit of Endocrinology National and Kapodistrian University of Athens, 17th Agiou Thoma GR-11527 Goudi, Athens (Greece)

a.angelousi@gmail.com 
Table 1. Classification of hypophysitis, incidence, histopathological characteristics, imaging, and treatment

\begin{tabular}{|c|c|c|c|c|}
\hline Causes & Incidence & Histopathology & Imaging & Treatment \\
\hline \multicolumn{5}{|l|}{ PH } \\
\hline LH $[1,3]$ & $\begin{array}{l}76-86 \% \text { of all } \mathrm{PH} \\
1 / 7-9 \times 10^{6} \text { cases }\end{array}$ & $\begin{array}{l}\text { focal or diffuse infiltration of lymphocytes } \\
\text { and occasional plasma cells, eosinophils, and } \\
\text { fibroblasts; pituitary fibrosis and atrophy may } \\
\text { occur in later stages of the disease }\end{array}$ & $\begin{array}{l}\text { isointense in T1-weighted images; suprasellar } \\
\text { extension with alteration of the optic chiasm ( } 64 \% \\
\text { of cases); thickening of the pituitary stalk }\end{array}$ & $\begin{array}{l}\text { hormone replacement treatment in case of } \\
\text { hypopituitarism; high-dose glucocorticoid } \\
\text { therapy; surgery for nonresponders }\end{array}$ \\
\hline $\operatorname{IgG4H}[26,93]$ & $\begin{array}{l}30 \% \text { of all } \mathrm{PH} \\
0.28-1.08 / 10^{5} \text { cases }\end{array}$ & $\begin{array}{l}\text { mononuclear infiltration of the pituitary gland, } \\
\text { rich in lymphocytes and plasma cells, with }>10 \\
\text { IgG4-positive cells/high-power field and } \\
\text { storiform fibrosis }\end{array}$ & $\begin{array}{l}\text { the radiological appearance does not help } \\
\text { differentiate between different types }\end{array}$ & $\begin{array}{l}\text { high-dose glucocorticoid therapy; hormone } \\
\text { replacement treatment in case of } \\
\text { hypopituitarism; B cell-depleting therapies }\end{array}$ \\
\hline $\mathrm{GH}[1,56,71]$ & $\begin{array}{l}20 \% \text { of all } \mathrm{PH} \\
1 / 10 \times 10^{6} \text { cases }\end{array}$ & $\begin{array}{l}\text { large numbers of multinucleated giant cells and } \\
\text { histiocytes with granuloma formation }\end{array}$ & $\begin{array}{l}\text { isointense in T1-weighted images; suprasellar } \\
\text { extension ( } 67 \% \text { of cases); pituitary enlargement is } \\
\text { the commonest feature; contrast enhancement and } \\
\text { pituitary stalk thickening }\end{array}$ & $\begin{array}{l}\text { glucocorticoid therapy appears to be less } \\
\text { effective compared with LH while surgical } \\
\text { resection leads to better symptom resolution }\end{array}$ \\
\hline $\mathrm{XH}[1,3,71]$ & $\begin{array}{l}3 \% \text { of } \mathrm{PH} \text { with only } \\
27 \text { cases reported in } \\
\text { the literature }\end{array}$ & $\begin{array}{l}\text { foamy histiocytes (lipid-rich macrophages) } \\
\text { without presence of granulomas, plasma cells, } \\
\text { or small round mature lymphocytes; pituitary } \\
\text { fibrosis may be seen in later stages of the disease }\end{array}$ & $\begin{array}{l}\text { hypointense in T1-weighted images; pituitary stalk } \\
\text { displacement without thickening }\end{array}$ & $\begin{array}{l}\text { glucocorticoid therapy appears to be less } \\
\text { effective compared to LH, but limited } \\
\text { clinical experience; complete, partial or no } \\
\text { recovery from mass effect of symptoms, but } \\
\text { endocrine deficiencies seldom recover }\end{array}$ \\
\hline NH [10] & $\begin{array}{l}\text { extremely rare, }<1 \% \\
\text { ( } 4 \text { case reports) }\end{array}$ & $\begin{array}{l}\text { diffuse nonhemorrhagic necrosis with } \\
\text { surrounding lymphocytes, plasma cells, and } \\
\text { eosinophils }\end{array}$ & $\begin{array}{l}\text { lack of enhancement of the enlarged pituitary gland } \\
\text { in T1-weighted images; thickening of the pituitary } \\
\text { stalk }\end{array}$ & $\begin{array}{l}\text { hormone replacement treatment in case of } \\
\text { hypopituitarism }\end{array}$ \\
\hline \multicolumn{5}{|l|}{ SH } \\
\hline \multicolumn{5}{|l|}{ Drugs } \\
\hline $\begin{array}{l}\text { ICIs (anti-CTLA-4 and } \\
\text { anti-PD-1/PD-L1) } \\
{[27,28,70]}\end{array}$ & $\begin{array}{l}1.5-17 \% \text { of cases } \\
\text { with ipilimumab and } \\
0.5-1.5 \% \text { with PD-1/ } \\
\text { PD-L1 }\end{array}$ & $\begin{array}{l}\text { T cell infiltration and IgG-dependent } \\
\text { complement fixation and phagocytosis; CTLA-4- } \\
\text { related hypophysitis: complement fixation, } \\
\text { macrophage infiltration, and lymphocyte } \\
\text { activation (type II and IV hypersensitivity } \\
\text { reaction) }\end{array}$ & $\begin{array}{l}\text { no obvious radiological patterns; diffuse } \\
\text { enlargement of the pituitary (up to } 60-100 \% \text { of } \\
\text { baseline size); enhancement after gadolinium; } \\
\text { suprasellar extension with compression and } \\
\text { displacement of chiasm is uncommon; posterior } \\
\text { pituitary is preserved in most cases }\end{array}$ & $\begin{array}{l}\text { in milder dysfunction: hormone } \\
\text { replacement treatment; in severe or } \\
\text { life-threatening cases: high-dose } \\
\text { glucocorticoids; discontinuation of the ICI }\end{array}$ \\
\hline \multicolumn{5}{|c|}{ Others: interferon-alpha, ustekinumab, ribavirin } \\
\hline \multicolumn{5}{|l|}{ Systemic diseases } \\
\hline Sarcoidosis [89] & $0.5 \%$ of cases & noncaseating granulomas & $\begin{array}{l}\text { normal; thickening of the pituitary stalk; suprasellar } \\
\text { lesion }\end{array}$ & treatment of the underlying disease \\
\hline $\begin{array}{l}\text { Granulomatous polyangiitis } \\
{[18,90]}\end{array}$ & $\begin{array}{l}\text { rare and late } \\
\text { manifestation of the } \\
\text { disease }\end{array}$ & $\begin{array}{l}\text { necrotizing granulomas and vasculitis in small- } \\
\text { and medium-sized blood vessels }\end{array}$ & $\begin{array}{l}\text { enlarged pituitary gland; heterogenous contrast } \\
\text { enhancement }\end{array}$ & $\begin{array}{l}\text { treatment of the underlying vasculitis } \\
\text { (steroids, cyclophosphamide) }\end{array}$ \\
\hline LCH [18] & $\begin{array}{l}40 \% \text { of cases; } \\
1-2 \times 10^{6} \text { new cases }\end{array}$ & $\begin{array}{l}\text { infiltration of the pituitary with Langerhans cells, } \\
\text { eosinophils, neutrophils, small lymphocytes, and } \\
\text { histiocytes }\end{array}$ & $\begin{array}{l}\text { infundibular enlargement; suprasellar mass; absence } \\
\text { of the bright spot of the posterior pituitary }\end{array}$ & $\begin{array}{l}\text { prednisone, alone or in combination with } \\
\text { vinblastine, cladribine, and vemurafenib; } \\
\text { desmopressin; hormone replacement } \\
\text { treatment }\end{array}$ \\
\hline $\begin{array}{l}\text { ECD (rare multisystem } \\
\text { non-Langerhans cell form) } \\
{[32,33]}\end{array}$ & $50-70 \%$ of cases & histiocytes with non-Langerhans features & $\begin{array}{l}\text { enlarged pituitary stalk and dural tail sign; } \\
\text { hyperintensities in T2-weighted images with and } \\
\text { without post-gadolinium enhancement }\end{array}$ & $\begin{array}{l}\text { vemurafenib, interferon-alpha, dabrafenib, } \\
\text { trametinib, cobimetinib, cladribine, } \\
\text { cyclophosphamide, and glucocorticoids }\end{array}$ \\
\hline $\begin{array}{l}\text { Anti-PIT-1 antibody syndrome } \\
\text { [34] }\end{array}$ & no data & pathogenesis similar to $\mathrm{LH}$ & $\begin{array}{l}\text { pituitary enlargement with symmetrical expansion } \\
\text { and intense and homogeneous enhancement of the } \\
\text { pituitary mass with gadolinium; presence of dural } \\
\text { tail sign; pituitary stalk is thickened but not deviated }\end{array}$ & $\begin{array}{l}\text { self-limiting and spontaneous remissions } \\
\text { can occur; glucocorticoids and rarely } \\
\text { surgery (when visual troubles); immune- } \\
\text { suppressive drug }\end{array}$ \\
\hline $\begin{array}{l}\text { Rosai-Dorfman disease } \\
\text { (a rare histiocytic disorder) } \\
\text { [36] }\end{array}$ & no data & $\begin{array}{l}\text { plasma cell infiltration, mixed with lymphocytes, } \\
\text { large histiocytes with foamy cytoplasm, and } \\
\text { Touton giant cells }\end{array}$ & $\begin{array}{l}\text { isointense } \mathrm{T} 1 \text { - and } \mathrm{T} 2 \text {-weighted images and } \\
\text { intensely enhancing with gadolinium }\end{array}$ & $\begin{array}{l}\text { surgery, radiotherapy, steroids, } \\
\text { immunosuppressive drugs, or interferon- } \\
\text { alpha and cladribine }\end{array}$ \\
\hline Tolosa-Hunt syndrome [37] & $1-2 / 10^{6}$ cases & $\begin{array}{l}\text { nonspecific granulomatous or } \\
\text { nongranulomatous inflammation }\end{array}$ & $\begin{array}{l}\text { enlargement of the pituitary with massive } \\
\text { infiltration or mimicking adenoma involving the } \\
\text { cavernous sinus }\end{array}$ & glucocorticoids \\
\hline Cogan's syndrome [3] & no data & granulomatous infiltration & $\begin{array}{l}\text { enlargement of pituitary gland and thickening of } \\
\text { stalk }\end{array}$ & glucocorticoids \\
\hline $\begin{array}{l}\text { Non-Hodgkin B cell lymphoma } \\
{[21-23]}\end{array}$ & 33 cases & B cell infiltration & $\begin{array}{l}\text { diffusely enlarged pituitary gland with invasion of } \\
\text { both cavernous sinuses }\end{array}$ & disease-specific treatment \\
\hline
\end{tabular}

Others: Crohn's disease, thymoma, infections (bacterial, viral, fungal)

ECD, Erdheim-Chester disease; ICI, immune checkpoint inhibitor; IgG4H, IgG4 hypophysitis; LCH, Langerhans cell histiocytosis; LH, lymphocytic hypophysitis; NH, necrotizing hypophysitis; PH, primary hypophysitis; $\mathrm{SH}$, secondary hypophysitis; $\mathrm{XH}$, xanthomatous hypophysitis. 
cal (adenohypophysitis, infundibulo-neurohypophysitis, and panhypophysitis), histopathological (lymphocytic, granulomatous, xanthomatous, IgG4, and necrotizing), or etiological (primary hypophysitis $[\mathrm{PH}]$ or secondary hypophysitis [SH]) criteria [3] (Table 1). Primary forms are characterized by an inflammatory process confined to the pituitary, whereas secondary forms develop secondary to systemic diseases, immunotherapeutic drugs, or other sella-related pathologies $[1,3]$.

In recent years, several new causative entities have been described. IgG4-related disease (IgG4-RD) and the introduction of immune checkpoint inhibitors (ICIs) as cancer therapies have prompted an increased interest in the role of inflammatory processes as a cause of $\mathrm{SH}[4,5]$.

Hypophysitis is a heterogenous entity that can be diagnosed with certainty following pituitary biopsy. However, the combination of clinical presentation and biochemical/hormonal abnormalities along with imaging findings is mostly used because biopsy can be associated with considerable morbidity. As the pathogenesis of $\mathrm{PH}$ remains incompletely understood, treatment is aimed at amelioration of compressive effects and replacement of existing or evolving hormonal deficits, whereas specific treatment is administered to $\mathrm{SH}$. In this review we summarize the current literature, including recently described causes of hypophysitis, and address areas of uncertainty along with anticipated diagnostic and therapeutic developments.

\section{Methods}

We performed a PubMed-based search up to October 2019 using the terms "hypophysitis," "adenohypophysitis/infundibulohypophysitis," "IgG4," "granulomatous," "immune checkpoint," "CTLA-4," and "PD-1/PD-L1" combined with "hypophysitis," "hypopituitarism," and "diabetes insipidus," producing 1,102 articles. We used filters to select articles in English $(n=963)$, related to humans $(n=751)$, and published the last 15 years $(n=426)$. Further shortlisting was based on their relevance based on the abstract, and after duplicate removal we identified 303 full-text articles (102 reviews/metanalyses, 188 case reports or case series, and 13 clinical studies, of which 85 were regarded as most relevant based on the full text (Fig. 1).

\section{Results}

\section{Variants of Hypophysitis}

The classification of hypophysitis is challenging and sometimes not clearly defined. Better understanding of the pathophysiological mechanisms and histopathologi-

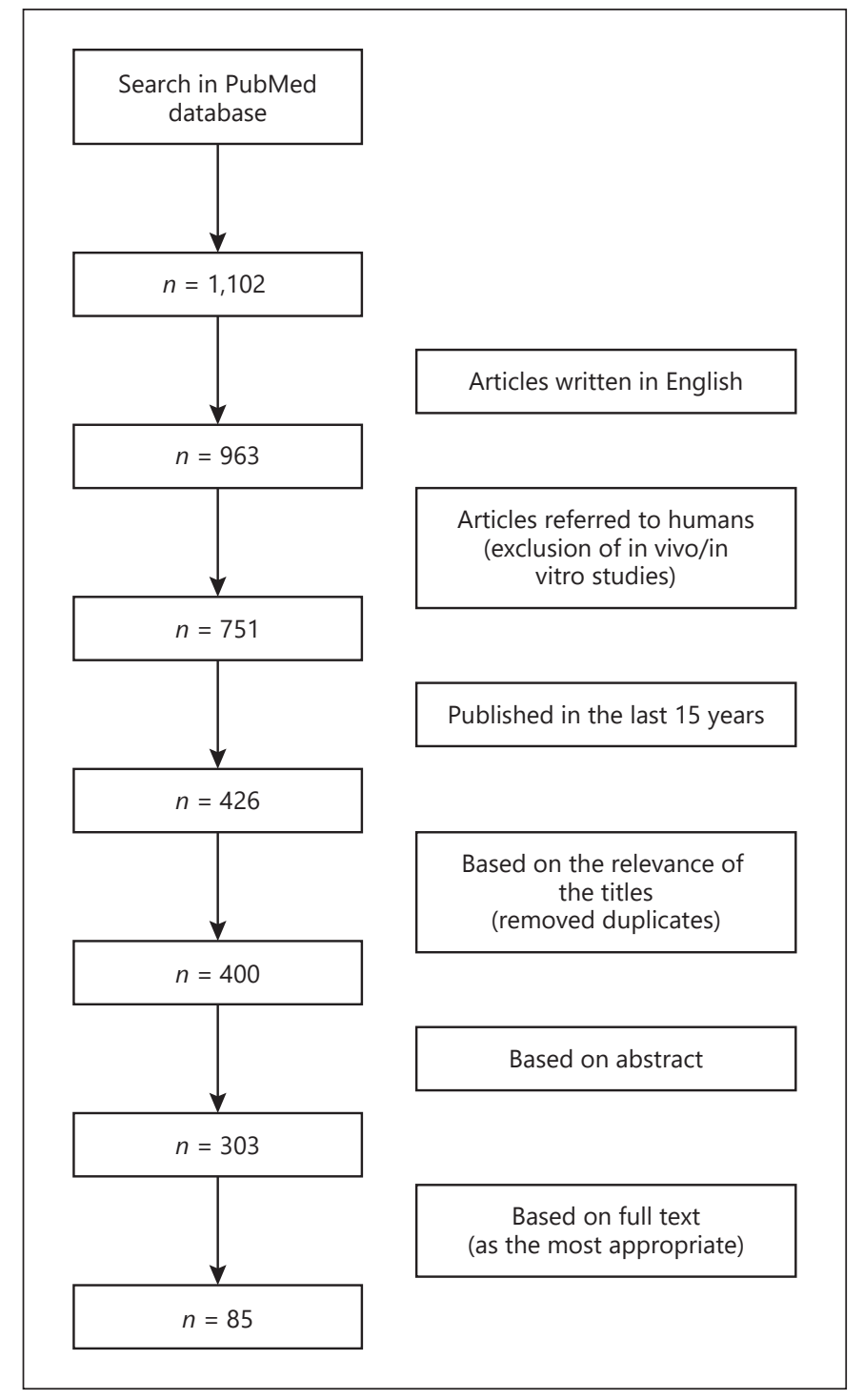

Fig. 1. Flow diagram of the PubMed database search.

cal findings has led to new consideration and reclassification for several forms of hypophysitis. Often, the clinical distinction between the different subtypes is difficult without biopsy as radiological and hormonal features can be incongruent with one another and with pathological findings.

$\mathrm{PH}$ classification is also still evolving since some consider $\mathrm{PH}$ variants to be truly distinct entities or idiopathic forms, whereas others consider them to be a different expression of the same autoimmune process due to the possible occurrence of mixed forms [6]. SH is caused by a variety of inflammatory, infectious, vascular, and neoplastic conditions or as an adverse effect of various med- 
ications. Autoimmune hypophysitis results from autoimmunity-mediated destruction of the pituitary gland and is the commonest form of hypophysitis, including most cases of the PH category as well as the systemic autoimmune diseases of the $\mathrm{SH}$ forms [7].

\section{Primary Forms}

Hypophysitis is relatively rare, accounting for approximately $0.24-0.93 \%$ of all pituitary diseases $[4,8]-$ with its incidence constantly increasing with the widespread use of ICIs - and $0.4 \%$ of pituitary surgical cases [9]. PH is the commonest form of autoimmune hypophysitis [7]. $\mathrm{PH}$ has an incidence of $1 / 9$ million/year and is classified according to etiology, anatomical location, and histopathology [4, 9]. Lymphocytic hypophysitis ( $\mathrm{LH})$ is the commonest subtype, whereas other subtypes of $\mathrm{PH}$ include granulomatous hypophysitis (GH), IgG4 hypophysitis $(\mathrm{IgG} 4 \mathrm{H})$, xanthomatous hypophysitis $(\mathrm{XH})$, and necrotizing hypophysitis $(\mathrm{NH})$ based on histological criteria $[1,3,10]$ (Table 1$)$. Classification by anatomical location of the pituitary includes adenohypophysitis, infundibulo-neurohypophysitis, and panhypophysitis.

$\mathrm{LH}$ is the commonest cause of $\mathrm{PH}$, accounting for 76$86 \%$ of cases, whereas $\mathrm{XH}$ represents one of the rarest forms of $\mathrm{PH}$, with 27 reported cases $[11,12]$. It is unclear whether XH constitutes a distinct entity or a continuum of the autoimmune/lymphocytic spectrum. Lately, XH has been considered an inflammatory condition most likely related to partial rupture of a Rathke's cleft cyst being classified as $\mathrm{SH}$ [13]. GH is a chronic inflammatory condition with an incidence of $1 / 10$ million affecting mainly females [14]. GH is considered either a primary entity, idiopathic $\mathrm{GH}$, or secondary to another pathology and constitutes a diagnosis of exclusion. In a review of 82 cases, GH was associated with pituitary lymphocytic infiltration and a mean age at presentation of 43 years [15].

$\mathrm{NH}$ is the rarest form of $\mathrm{PH}(0.6 \%)$, with a female/male ratio of 3:1, of unknown etiology that can occur as $\mathrm{SH}$ or ICI-induced hypophysitis $[6,16,17]$.

Mixed forms of hypophysitis are observed in $4 \%$ of $\mathrm{PH}$ cases [6]. Lymphogranulomatous hypophysitis may include features of LH and GH, but most likely presents a transition from an initial lymphocytic infiltrative pattern of LH to a more granulomatous, chronic inflammatory pattern [6]. Xanthogranulomatous hypophysitis contains both foamy xanthoma cells and multinucleated giant cells with cholesterol clefts and hemosiderin deposits [6]. XH is the earlier manifestation, followed by xanthogranulomatous hypophysitis changes that occur later during the course of the disease [13].
Table 2. Diagnostic criteria for IgG4H

\section{Criteria}

Histopathology

mononuclear infiltration of the pituitary gland, rich in lymphocytes and plasma cells, with $>10$ IgG4positive cells/high-power field

\begin{tabular}{ll}
\hline MRI & sella mass or thickened pituitary stalk \\
\hline Biopsy & involvement of other organs \\
\hline Serology & IgG4 $>140 \mathrm{mg} / \mathrm{dL}$ \\
\hline Treatment & $\begin{array}{l}\text { clinical and radiological improvement } \\
\text { with corticosteroids }\end{array}$ \\
\hline Established diagnosis & 1 or $2+3$ or $2+4+5$
\end{tabular}

IgG4H, IgG4 hypophysitis; MRI, magnetic resonance imaging.

\section{Secondary Forms}

$\mathrm{SH}$ results from drug administration, autoimmune diseases, systemic inflammatory processes, or infections $[1,3,10]$ (Table 1). After excluding drug-induced hypophysitis, the commonest cause is granulomatous disease. Most pituitary granulomas are due to a specific entity such as histiocytosis, sarcoidosis, syphilis, tuberculosis, or in the context of granulomatous polyangiitis. Infiltrative diseases such as Langerhans cell histiocytosis (LCH) [18] and rarely hemochromatosis are also implicated [19]. SH may be diagnosed in preexisting sella pathologies [20]. Pituitary infections complicated by SH develop via hematogenous spread, contiguous extension to the central nervous system, or following cranial surgery. HIV- and neurosyphilis-induced hypophysitis has also been reported [16-18]; primary pituitary lymphoma may also present as hypophysitis [21-23].

New Causes of Hypophysitis

Recently, IgG4H either isolated or in the context of IgG4-RD has also been described [21, 22, 24]. Its incidence is $0.28-1.08 / 100,000$ patients, comprising $30 \%$ of all hypophysitis and $4 \%$ of all hypopituitarism cases [17, 18]; however, it may be underreported, as histological/ immunohistochemical analysis revealed that $41.4 \%$ of LH cases fulfilled the criteria for IgG4H [25]. It usually occurs in the 7th decade with a male predominance [3]; a distinct subset of IgG4-RD with female predominance has also been described [25]. The diagnosis of IgG4H is confirmed by characteristic histopathological findings at pituitary biopsy, and it is considered a subtype of autoimmune hy- 
pophysitis. Since pituitary biopsy is an invasive procedure, specific diagnostic criteria have been proposed including histopathological findings, radiological findings on magnetic resonance imaging (MRI), serum IgG4 levels, and response to glucocorticoids [26] (Table 2).

Hypophysitis is one of the commonest endocrinopathies associated with ICI mainly observed with the antiCTLA-4 agent ipilimumab $[9,27,28]$. Its incidence varies between $0.5 \%-18 \%$, and is dose-dependent, ranging from $0.5 \%$ with a dose of $3 \mathrm{mg} / \mathrm{kg}$, up to $18 \%$ with a dose of $10 \mathrm{mg} / \mathrm{kg}$ being more frequent in men and the elderly [2, $9,27]$. In one meta-analysis of 6472 patients treated with ICI, only $1.3 \%$ developed hypophysitis [29], whereas in another $5.6 \%$ of 19,922 patients treated with ipilimumab developed hypophysitis compared to $0.5-1.5 \%$ treated with anti-PD-1/PD-L1 agents [30]. ICI-induced hypophysitis is less common with anti-PD-1/anti-PD-L1 monotherapy with a $4.8 \%$ prevalence in patients treated with the anti-PD-1 agent pembrolizumab [29]. The median time of onset of hypophysitis for ipilimumab is 9 weeks and 3.3-4.9 months for anti-PD-1s [2]. Combining antiCTLA-4 with anti-PD-1 agents causes earlier development of hypophysitis [31]. Other drugs that have also been associated with hypophysitis are shown in Table 1.

Erdheim-Chester disease (ECD) is a rare non-LCH form of histiocytosis of clonal myeloid progenitor cells bearing a BRAF-V600E mutation affecting the pituitary [32]. ECD can also give rise to xanthomatous or xanthogranulomatous lesions in the pituitary and must be suspected in apparent $\mathrm{XH}$ cases with multiorgan involvement [2]. In a recent French study, 91\% of patients had anterior pituitary deficiency, whereas diabetes insipidus (DI) was reported in 33\% of cases [33].

In other autoimmune pituitary diseases, specific anterior pituitary defects have been reported. Recently, a unique autoantibody against pituitary-specific transcription factor 1 (PIT-1) was detected in patients with acquired defects of growth hormone, prolactin, and thyroid-stimulating hormone (TSH) $[34,35]$. This syndrome named "anti-PIT-1 antibody syndrome" is considered to be a cytotoxic T cell-mediated autoimmune process causing hypophysitis (anti-PIT-1H) [34, 35]. The following criteria have been suggested for the diagnosis of anti-PIT$1 \mathrm{H}[34]$ : (1) acquired specific growth hormone, TSH, and prolactin deficiencies without impairment of other pituitary axes; (2) circulating anti-PIT-1 antibodies or PIT1-reactive cytotoxic T lymphocytes; (3) underlying diagnosis of a thymoma or another malignant neoplasm exhibiting ectopic expression of anti-PIT-1 antibodies. A definitive diagnosis is established if criteria 1 and 2 are

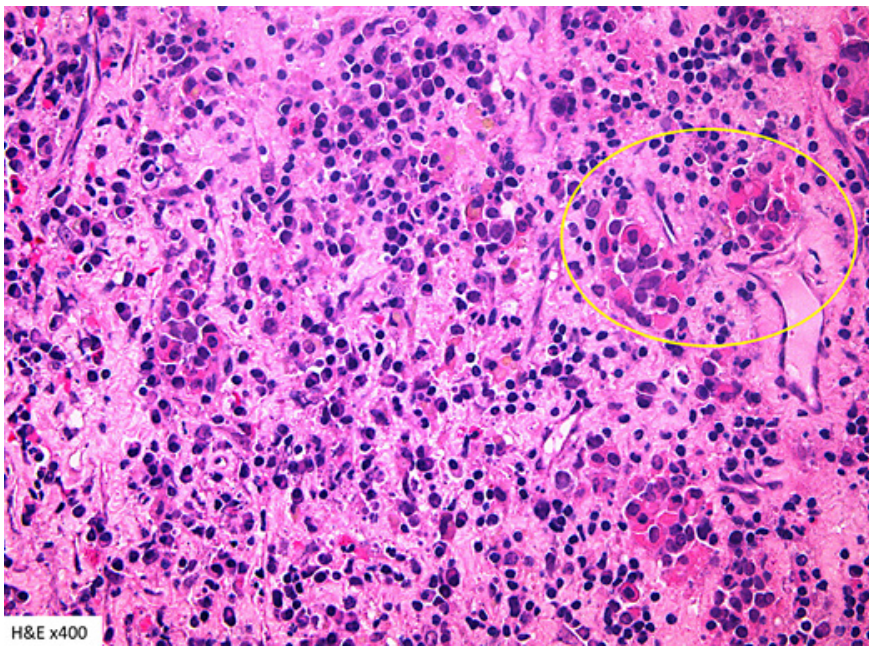

Fig. 2. Histopathological image of a case with lymphocytic hypophysitis. Lymphoplasmacytic infiltration and disruption of the normal architecture of the anterior lobe of the pituitary gland.

met, whereas the presence of criterion 1 alone suggests a probable diagnosis. Criterion 3 may help the diagnosis and clarify pathogenesis, but may not be necessarily obvious at the time of diagnosis based on endocrine abnormalities. Other rarer causes of $\mathrm{SH}$ are presented in Table $1[36,37]$.

\section{Pathogenetic Mechanisms}

$\mathrm{LH}$ is an immune-mediated inflammatory disorder characterized by diffuse infiltration of the pituitary by lymphocytes and variable degrees of fibrosis [7] (Fig. 2). Several pituitary antibodies against alpha-enolase, gamma-enolase, pituitary gland-specific factors 1 and 2, secretogranin 2, chorionic somatomammotropin, and corticotroph-specific transcription factor (TPIT) have been described $[6,38,39]$. In addition, anti-hypothalamic antibodies targeting corticotrophin-releasing hormone-secreting cells as well as antibodies directed against somatotroph, lactotroph, gonadotroph, and corticotroph cells causing selective hormonal deficiencies have also been identified [6]. However, the pathogenicity of these antibodies is not yet confirmed due to lack of high sensitivity and specificity [6]. Recently, two different patterns of immunological involvement have been identified in LH patients demonstrating higher numbers of $\mathrm{T}$ than $\mathrm{B}$ lymphocytes [40]. The first is an autoimmune process with $\mathrm{T}$ helper cell predominance without regulatory $\mathrm{T}$ cells and with few B lymphocytes with CD3+ T lymphocytes also costaining for CD4 in this pattern of LH. In the second, the lymphocytic infiltration is more organized, forming 


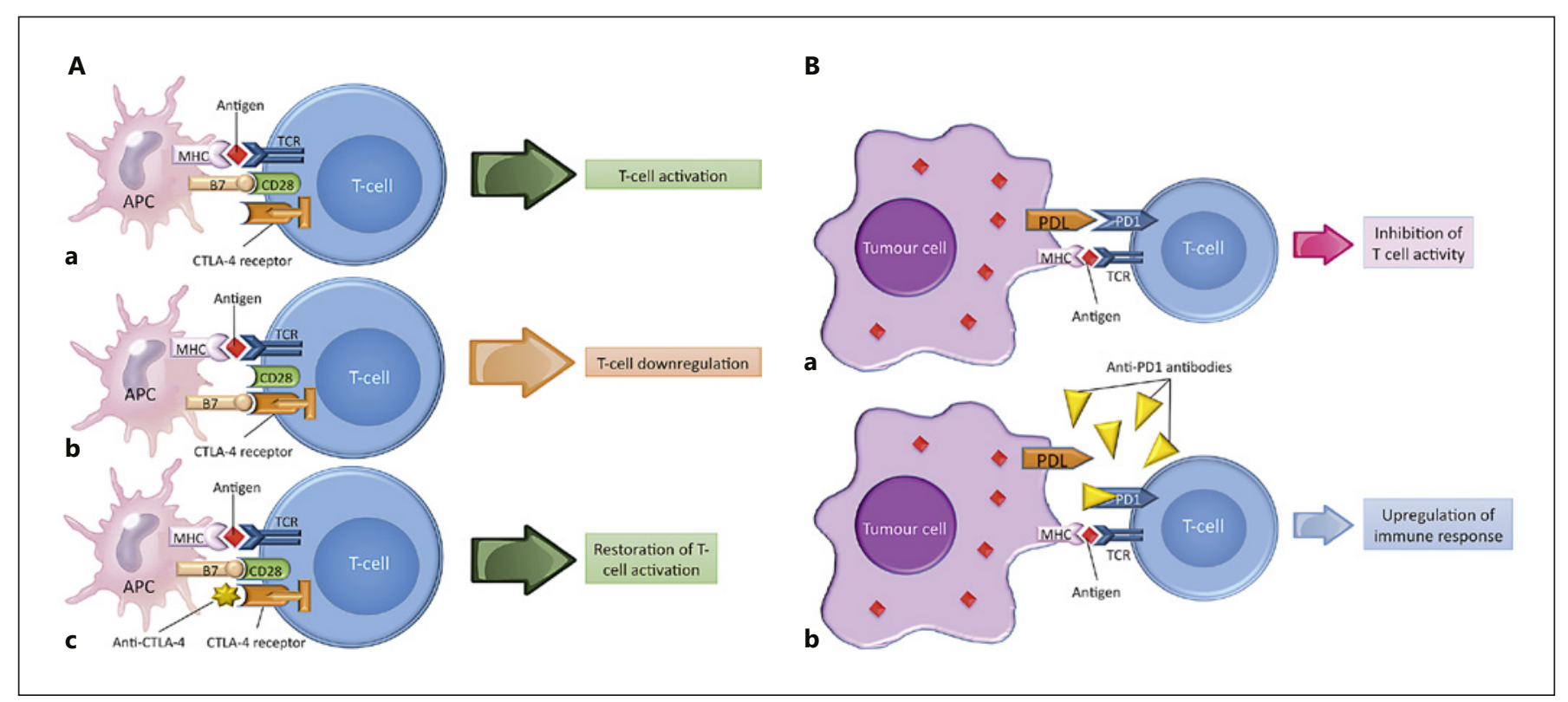

Fig. 3. A Immune checkpoint inhibitors, the CTLA-4 pathway. a The tumor-associated antigen is presented by the major histocompatibility complex (MHC) on the antigen-presenting cell (APC) and recognized by the T cell receptor (TCR) of the T cell. Binding B7 on the APC with the CD28 receptor on the T cell is the second signal required for the activation of the $\mathrm{T}$ cell and the initiation of the immune response against the tumor cells. b CTLA-4 is a homolog of CD28 and limits proliferative response of activated T cells competing with CD28 for ligand B7. This inhibition occurs in response to binding of $\mathrm{B} 7$ on APC with CTLA- 4 receptor on the $\mathrm{T}$ cell and interrupts the second signal. c Anti-CTLA-4 antibodies block CTLA-4 and restore $\mathrm{T}$ cell activation and proliferation.

germinal centers with a relatively higher number of $\mathrm{B}$ lymphocytes, whereas most CD3+ cells stain positive for CD8.

The pathogenesis of $\mathrm{XH}$ remains unclear owing to the extremely small case numbers, and although it was first thought to be due to an infectious agent, more recent work suggest that $\mathrm{XH}$ may be a reactive hypophysitis occurring secondarily to a ruptured Rathke's cleft cyst [6, $12,41]$. The histological findings of a metaplastic epithelium support this hypothesis. However, the precise etiology for rupture of a Rathke's cleft cyst remains unclear, although an association with pituitary apoplexy has been postulated.

The pathophysiology of ICI-induced hypophysitis is not well understood. Although it is conceivable that activation of the immune system may aggravate autoimmunity, this does not explain why hypophysitis is more frequently observed with the anti-CTLA-4 agent ipilimumab compared to anti-PD-1/PD-L1 agents $[2,4,42]$.
B Immune checkpoint inhibitors, the PD-1 pathway. PD-1 is an immune cell-specific surface receptor, and ligands for PD-1 (PD$\mathrm{L} 1$ and PD-L2) are associated proteins that are found on APCs and cancer cells. When bound to a ligand, PD-1 lowers the threshold for apoptosis, induces anergy via blunted TCR signaling, and generally leads to $\mathrm{T}$ cell depletion. a In certain tumor cells, upregulation of PD-L1 expression has been observed, which leads to increased inhibition of $\mathrm{T}$ cell activity in favor of tumor cell survival. b A monoclonal antibody against PD-1 can block this pathway and result in upregulation of immune response and inhibition of tumor growth. Figure reproduced with permission of S. Karger AG, Basel from the original source [44].

Recent studies in mouse and human pituitary glands have revealed that anti-CTLA-4 hypophysitis is characterized by the presence of circulating anti-pituitary antibodies and lymphocytic infiltration of the gland [43]. Ectopic expression of CTLA- 4 has also been observed in the normal hypophysis in mice, particularly in prolactin- and TSH-secreting cells [43], as well as in hypophysitis and adenomas of the human pituitary gland [17, 44] (Fig. 3).

Anti-PIT-1H is associated with circulating anti-PIT-1 antibodies, which are specific markers for this condition. However, cytotoxic T lymphocytes are actually responsible for its development as circulating antibodies do not exhibit cytotoxic properties, but rather serve as biomarkers for anti-PIT-1H [45]. Recent experiments have demonstrated that PIT-1 protein epitopes are presented by the MHC/HLA class I on the pituitary cells, further suggesting cytotoxic $\mathrm{T}$ lymphocyte-mediated destruction in this disorder [45]. 


\section{Diagnosis of Hypophysitis}

The only definitive way to provide an unequivocal diagnosis of $\mathrm{PH}$ is through pituitary biopsy and histopathological examination [1] (Fig. 2). However, the procedure is invasive and may not be necessary unless the management outcome of biopsy outweighs its risks. In daily practice, clinical, biochemical/endocrinological, and imaging features should be enough to formulate a differential diagnosis and guide treatment accordingly. The histopathology of LH demonstrates the characteristic infiltration of lymphocytes into the pituitary gland, in the interstitium and pituitary acini, occasionally arranging themselves into lymphoid follicles with germinal centers $[6,46]$. The density of lymphocytes is higher in LH compared to other forms of $\mathrm{PH}$, and the lymphocytes can often be accompanied by plasma cells $[38,46]$. The end result of LH is pituitary fibrosis, which can often be severe. The amount of lymphocyte infiltration correlates inversely with the degree of fibrosis. XH is characterized by the presence of lipid-rich foamy histiocytes with a variable number of lymphocytes $[1,47]$. The diagnosis of $\mathrm{XH}$ is only confirmed on tissue sections demonstrating foamy (xanthomatous) macrophages with or without cholesterol clefts, admixed with variable amounts of multinucleated giant cells [12]. In GH the pituitary is infiltrated by histiocytes, multinucleated giant cells, and lymphocytes along with plasma cells $[15,39$, 48]. The histopathology of NH reveals extensive areas of necrosis with infiltration of lymphocytes, plasmatocytes, and few eosinophils leading to fibrosis $[6,49]$.

\section{Clinical and Endocrine Findings}

Differential diagnosis of the variants of hypophysitis is not always possible due to significant overlap between the clinical symptoms and absence of pathognomonic characteristics. Sex predominance and age at presentation can be additional criteria as $\mathrm{LH}, \mathrm{GH}$, and $\mathrm{XH}$ occur more frequently in females (female/male ratio of 8.5:1) [4, 50-52]. Many cases of $\mathrm{LH}(40 \%)$ occur in late pregnancy or in the peripartum period $[4,50,52]$, whereas GH occurs in older age and is not associated with pregnancy. Similarly to $\mathrm{LH}, \mathrm{XH}$ occurs mainly during the 4 th decade. Unlike pituitary adenomas, the extent of hormonal impairment in hypophysitis is often disproportionate to the size of the lesion on MRI $[4,53,54]$.

Headache $(50 \%)$ is the most frequent symptom in any type of $\mathrm{PH}$, followed by adrenal insufficiency (10-40\%) and hyperprolactinemia (20\%) [35, 37]. In LH, adrenocorticotropic hormone followed by TSH deficiency are most commonly reported $[1,55]$. It has been suggested that hyperprolactinemia is predominantly seen in the acute phase of LH [53]. Symptoms related to posterior pituitary infiltration or the stalk are less frequent [4]. In $\mathrm{GH}$, headaches are found in $61 \%$, visual changes in $40 \%$ $[3,15,56]$, polyuria/polydipsia in $27 \%$, and cranial nerve palsies in $27 \%$ of cases [3]. In XH, visual disturbances and DI are rarely reported and anterior pituitary impairment is less severe compared to $\mathrm{LH}[38,47,57]$. In contrast to $\mathrm{LH}$, gonadotropin and growth hormone deficiencies are common in XH [38]. Involvement of the cavernous sinus with ophthalmoplegia is relatively rare [55,58]. Although the clinical and imaging features are similar to other forms of hypophysitis, $\mathrm{NH}$ is more likely to present more acutely with mass effect symptoms (e.g., eye pain, visual defects) or even as aseptic meningitis [10,38].

In IgG4H, anterior pituitary deficiency and DI develop in $48 \%$ [59]. Patient history and clinical presentation are useful tools in differentiating IgG4H from LH $[1,60]$. IgG4-RD can cause panhypopituitarism, anterior hypopituitarism, or isolated DI in 50,25 , and $18 \%$ of cases, respectively [61, 62]. The diagnosis of ICI-induced hypophysitis is based on recent use of these drugs in patients with malignancies. The commonest symptoms include fatigue and headaches in $59-73 \%$ and $21-80 \%$ of cases, respectively, whereas visual disturbances and DI are relatively rare $[9,43,63-65]$. Most cases are diagnosed during regular follow-up of pituitary function performed before every cycle of therapy for at least the first 3 months [1]. Patients with ICI-induced hypophysitis usually present with TSH (84\%), adrenocorticotropic hormone (80\%), and gonadotropin (76\%) deficiency $[39,65]$.

In $\mathrm{SH}$, clinical presentation may not be disease-specific. In sarcoidosis-induced hypophysitis hypogonadism (87.5-89\%), hypothyroidism (56\%), hypocortisolism (37\%), and growth hormone deficiency (30\%) are common. The commonest endocrine abnormality, reported in $30 \%$ of patients with $\mathrm{LCH}$, is DI, although anterior pituitary deficiencies can occur either at presentation or during follow-up $[18,66,67]$. These patients usually have multiorgan and craniofacial involvement, although localized disease of the hypothalamic-pituitary region has also been reported [66]. Identification of BRAF-V600E mutation in the peripheral blood or cerebrospinal fluid rules out other pathologies, but cannot distinguish LCH from ECD [68]. The commonest pituitary involvement in hemochromatosis is hypogonadism. Pituitary involvement is a rare and late manifestation of granulomatous polyangiitis, mainly causing hypogonadism and DI [20].

Approximately $30 \%$ of infection-induced hypophysitis present with partial or complete hypopituitarism, whereas DI has rarely been reported [20]. After treatment 
Fig. 4. a, b Magnetic resonance imaging T1 sequence sagittal (a) and coronal (b) imaging of a patient diagnosed with $\mathrm{LH}$. c, d Magnetic resonance imaging $\mathrm{T} 1$ sequence sagittal (c) and coronal (d) imaging 6 months after diagnosis and treatment of replacement with corticoids.
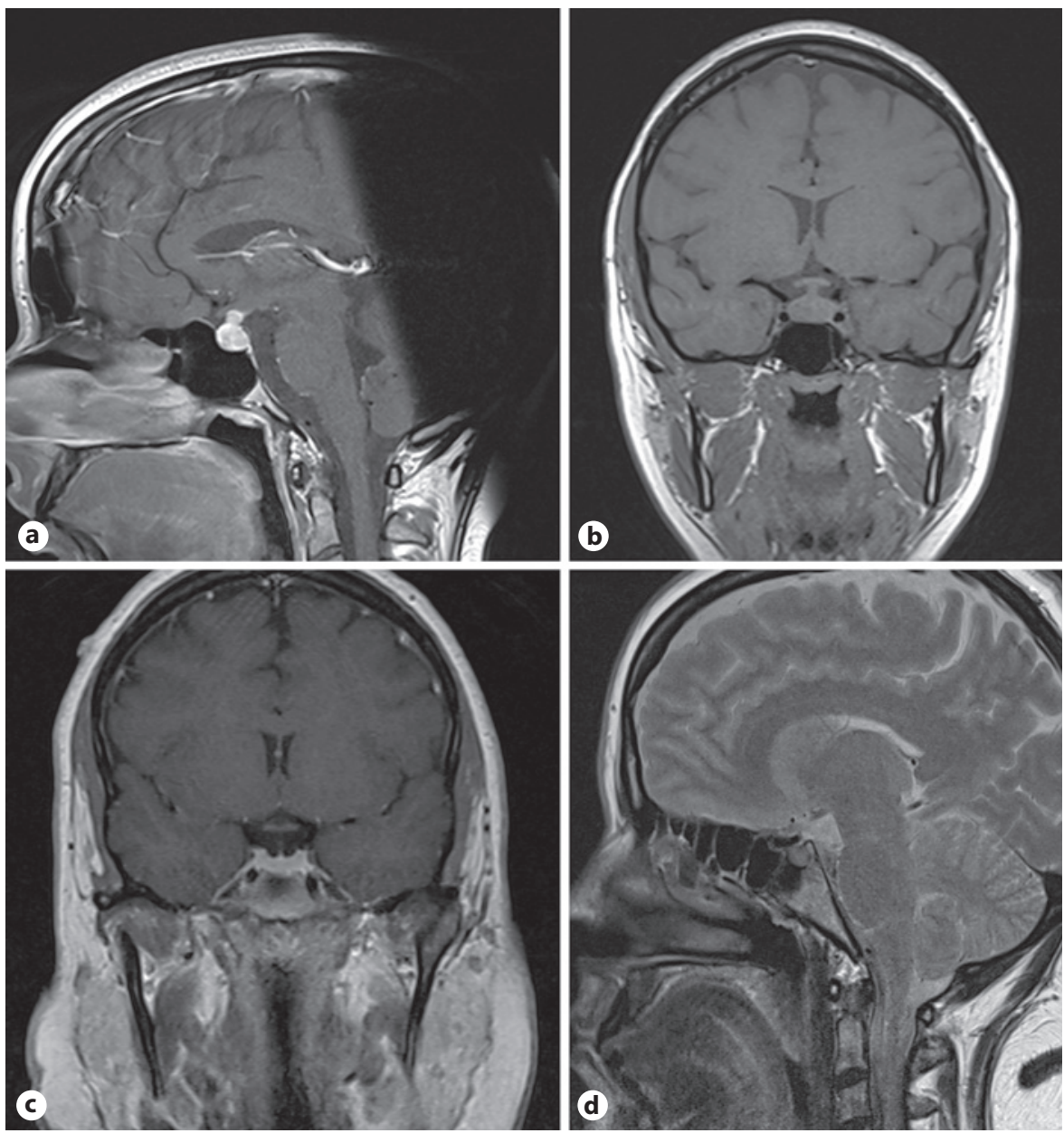

with anti-tuberculous drugs, the pituitary tuberculoma may disappear, with restoration of hypopituitarism in some cases [69].

Clinical manifestations are not always typical of a precise form of hypophysitis and in general severe headaches, visual disturbances due to chiasmal compression, and symptoms of hypopituitarism are the commonest presentations of hypophysitis. Less frequently, inflammation can primarily involve the posterior pituitary and the stalk, presenting with symptoms related to DI. Patients on ICI therapy often present with headache and anterior hypopituitarism, whereas those with IgG4H tend to present with more variable clinical features including headache, visual field defects, fever, weight loss, hypopituitarism, and/or DI. Since several subtypes of hypophysitis may be secondary to a systemic condition or an infiltrate disorder, it is important for the clinician to consider a broad clinical history and physical examination, especially in cancer patients on newer oncological medications.
Imaging Findings

Gadolinium-enhanced pituitary MRI is the preferred modality to define pituitary pathology. MRI is initially performed and monitored during the first 3 months of follow-up and thereafter according to disease progression [70]. Features suggestive of hypophysitis include an intense and enlarged triangular- or dumbbell-shaped homogenously enhancing gland with a thickened but not deviated stalk and absence of the posterior pituitary bright spot in patients with DI [71]. Empty sella may also represent a late finding in hypophysitis $[53,72]$. The presence of pituitary stalk thickening, in the appropriate clinical setting, is perhaps the strongest predictor of an inflammatory process [71]. These features are most prominent in LH that exhibits symmetric pituitary enlargement, pre-contrast homogeneity, and strips of involved area which resembles contrast-enhancing tissue along the dura mater, termed "dural tail" or "meningeal tail" $[1,4$, 73] (Fig. 4). MRI-specific findings for GH, albeit less well 
described, include pituitary enlargement and pituitary stalk thickening [56]. XH presents as cystic sellar mass, peripherally enhancing on post-gadolinium contrast images [71]. NH shows nonspecific MRI findings, including symmetrical enlargement of the pituitary gland without signs of hemorrhage, and thickened and pathologically enhancing stalk [53].

The imaging appearances on MRI of the different types of $\mathrm{PH}$ are quiet similar, whereas differentiating hypophysitis from other sellar lesions, mainly pituitary adenoma, is difficult (Table 1) [56]. A radiological score based on eight predictors has been developed to differentiate $\mathrm{PH}$ from pituitary adenomas, with a $92 \%$ sensitivity, a $99 \%$ specificity, and $97 \%$ both positive and negative predictive values $[53,55,74]$. The score ranges from -13 to +8 , and a score $\geq 1$ is suggestive of an adenoma, whereas a score $\leq 0$ is suggestive of hypophysitis [74] (Table 3). Recently, fluorodeoxyglucose $\mathrm{F} 18$ positron emission tomography is used in patients with inflammatory pituitary conditions, particularly in IgG4-RD and in LCH $[15,61,94]$.

Hypophysitis is a challenging radiological diagnosis which should be primarily differentiated from pituitary adenomas, pituitary metastases, and from other sellar/ parasellar tumors. MRI is considered the imaging of choice. Presence of pituitary stalk thickening as well as pituitary expansion with gadolinium enhancement are the strongest predictors of an inflammatory process in the pituitary gland. However, in cases of spontaneously resolution, absence of MRI findings at the time of investigation does not rule out long-standing autoimmune hypophysitis, and thus some cases of isolated hypopituitarism may represent a late or "missed" presentation of hypophysitis.

\section{Treatment}

The natural history of $\mathrm{PH}$ is variable, without therapeutic protocols based on established evidence [55]. Most of the literature refers to $\mathrm{LH}$, whereas data for other histological subtypes are scarce. It is important to distinguish between the acute phase of hypophysitis, which may require systemic treatment, and the chronic phase, which often evolves to fibrosis and pituitary atrophy, for which only treatment of hypopituitarism is needed [53]. Although regular surveillance is recommended for the chronic forms, only $4 \%$ of patients with LH had spontaneous remission with recovery of pituitary function, while most required long-term replacement of established hormonal deficiencies $[4,55]$.

In cases of progressive/recurrent $\mathrm{LH}$, immunosuppressive agents have been used [75], but data on glucocor-
Table 3. Radiological features to distinguish autoimmune hypophysitis from nonsecreting pituitary adenoma (by Gutenberg et al. [74])

\begin{tabular}{ll}
\hline Features & Score \\
\hline Related to pregnancy & \\
$\quad$ Yes & -4 \\
Pituitary mass volume & 2 \\
$\quad 6 \mathrm{~cm}^{3}$ & 3 \\
Asymmetry & -1 \\
Gadolinium enhancement type & \\
$\quad$ Medium/high & 1 \\
Gadolinium enhancement features & -2 \\
$\quad$ Heterogenous & -5 \\
Loss of the posterior pituitary bright spot & 2 \\
Enlarged stalk size & \\
Mucosal swelling & \\
\hline
\end{tabular}

ticoid administration are controversial [38]. An overall relapse rate following glucocorticoid withdrawal of $38 \%$ in $\mathrm{PH}$ has been described that developed 2-17 months after tapering, without correlation with glucocorticoid dose or treatment duration [58]. Presence of central DI was considered an unfavorable prognostic factor for response to glucocorticoids [76]. However, a recent study showed that presence of anti-pituitary antibody, central DI, absence of "bright spot" on MRI, and pituitary stalk $>3.9 \mathrm{~mm}$ correlated with a better responsiveness to glucocorticoids in LH [77].

As long-term treatment with glucocorticoids is associated with adverse effects, glucocorticoid-sparing agents have been used [58]. Azathioprine is most commonly used, leading to pituitary mass reduction in $84 \%$ of cases, improvement of anterior/posterior pituitary function in 45 and $41 \%$, respectively, and a $14 \%$ overall risk of relapse [78]. Rituximab, an anti-CD20 antibody that specifically depletes B lymphocytes, can be an effective treatment for patients with steroid-refractory B cell-predominant LH [79]. Remission of LH was observed in all reported cases using rituximab, and in one case remission was maintained even 3 years after treatment [79-81]. Glucocorticoid therapy is less effective in $\mathrm{GH}$ and $\mathrm{XH}$ compared to $\mathrm{LH}[3,30]$.

Surgery should be considered only in cases with serious and progressive visual field deficits and deterioration of visual acuity not responsive to medical treatment [3, $82,83]$. Moreover, surgery provides a histological diagnosis to guide future management [83]. The rate of recurrence/relapse of $\mathrm{PH}$ after surgery is $11-25 \%[3,41,51,52]$. Only a few cases of LH have been treated with stereotactic 
Table 4. CTCAE in ICI-induced hypophysitis

\begin{tabular}{lllll}
\hline & Grade 1 & Grade 2 & Grade 3 & Grade 4 \\
\hline $\begin{array}{l}\text { Pituitary } \\
\text { disorders }\end{array}$ & $\begin{array}{l}\text { asymptomatic or mild } \\
\text { symptoms; clinical or } \\
\text { diagnostic observation } \\
\text { only; intervention not } \\
\text { indicated }\end{array}$ & $\begin{array}{l}\text { moderate, minimal, or } \\
\text { noninvasive intervention } \\
\text { indicated; limiting age- } \\
\text { appropriate instrumental } \\
\text { activities of daily living }\end{array}$ & $\begin{array}{l}\text { severe or medically significant but } \\
\text { not immediately life-threatening } \\
\text { hospitalization prolongation of } \\
\text { existing hospitalization indicated; } \\
\text { disabling; limiting self-care }\end{array}$ & $\begin{array}{l}\text { life-threatening } \\
\text { consequences; urgent } \\
\text { intervention indicated }\end{array}$ \\
\hline
\end{tabular}

CTCAE, Common Terminology Criteria for Adverse Events; ICI, immune checkpoint inhibitor.

Fig. 5. Therapeutic approach in patients with hypophysitis. ICI, immune checkpoint inhibitor; MRI, magnetic resonance imaging.

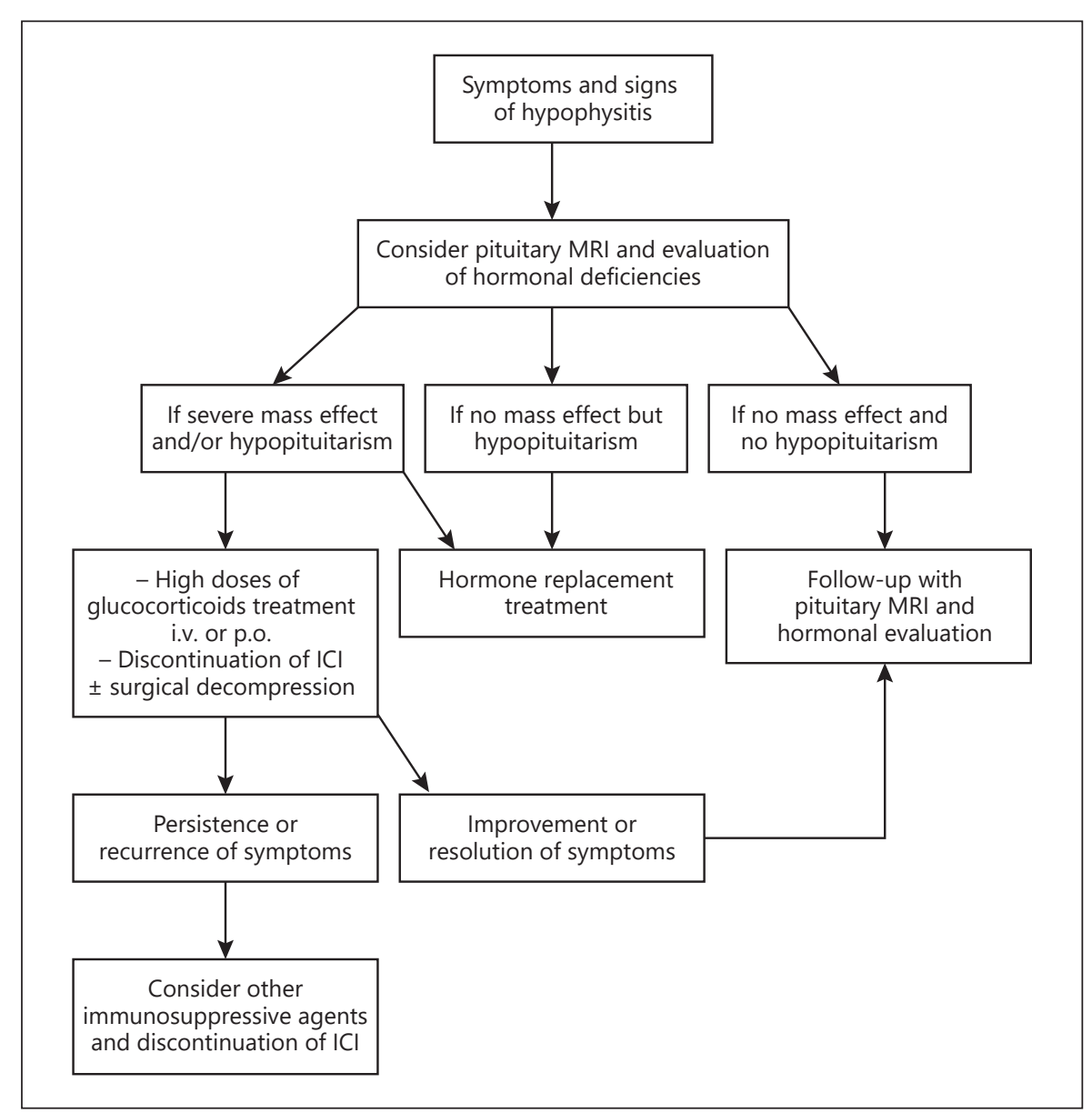

radiotherapy, leading to resolution of symptoms after 2 weeks to 6 months $[39,66]$. Radiation-induced hypopituitarism is observed in $20-30 \%$ of patients, typically occurring within the first 5 years following radiosurgery [84].

IgG4-RD should be promptly treated to revert symptoms and prevent fibrosis; prednisone $30-40 \mathrm{mg} /$ day induces remission of symptoms within a few weeks and is then tapered gradually over 2-6 months [85]. However, some patients may benefit from long-term maintenance glucocorticoid therapy, especially in cases of multiorgan involvement. Rituximab has been used in patients with poor response to glucocorticoids, albeit with higher relapse rates [85]. In some cases of $\operatorname{IgG} 4 \mathrm{H}$, spontaneous remissions have also been described [86].

In ICI-induced hypophysitis, the therapeutic management depends on the grading of the hypophysitis. In mild or moderate cases (grades 1 and 2 according to Common Terminology Criteria for Adverse Events [CTCAE] $\mathrm{v} 4.03$ ), simple surveillance with replacement of pituitary hormonal deficiencies is adequate without interruption 
of the ICI. In severe forms (grades 3 and 4 according to CTCAE v4.03), high-dose of glucocorticoids may be required with interruption, at least temporarily, of the ICI agent (Table 4).

Hypophysitis secondary to LCH should be treated with prednisone, alone or in combination with vinblastine, and cladribine, alongside with other pituitary hormone replacements in case of hypopituitarism [20]. Vinblastine and steroid-based therapy are suggested as the first-line options by the Histiocyte Society guidelines (Table 1) [87]. A positive response to the BRAF inhibitor vemurafenib has been described in patients with BRAFV600E-mutated LCH [88]. The treatment options for ECD include vemurafenib, interferon-alpha, cladribine, and glucocorticoids (Table 1) [2].

Most patients with sarcoidosis are treated with highdose glucocorticoids, whereas $50 \%$ also receive other immunomodulators. In one study only $13 \%$ showed improvement of existing pituitary deficiencies, with an allcause mortality of $8.7 \%$ [89]. There is no consensus on the best therapy strategy for granulomatous polyangiitis hypophysitis [3]. Although glucocorticoids with cyclophosphamide are the mostly used, no differences in the outcome of pituitary function are seen when compared with other immunosuppressive agents [90].

An algorithm of the therapeutic approach to hypophysitis is summarized in Figure 5. Treatment with high-dose glucocorticoids may be of value in reducing the mass effect, but there is little evidence of its role in facilitating recovery of pituitary function. Surgery is rarely indicated, but may be considered when glucocorticoid therapy has failed to reduce symptoms of mass effect or when the diagnosis remains questionable and tissue diagnosis is required. Discontinuation of ICI is reserved only for severe cases of hypophysitis as it did not improve the outcome of hypophysitis or hypophysitis-related hypopituitarism when compared to patients who remained on therapy. Patients with IgG4-RD and multiorgan involvement may benefit from long-term physiological glucocorticoid therapy. In cases of progressive or recurrent disease, highdose glucocorticoid therapy and glucocorticoid-sparing regimens may be considered.

\section{Recent Advances and Evolving Markers}

New serological markers are likely to serve as noninvasive diagnostic tools. The HLA markers DQ8 and DR53 are used to identify patients with LH since there is a 23.1fold increase in DQ8 levels in LH compared to other pituitary pathologies [91]. The role of anti-pituitary antibodies in autoimmune hypophysitis is still debated be- cause of several methodological problems leading to a low sensitivity and specificity of the method. Recently, a new target autoantigen, anti-rabphilin $3 \mathrm{~A}$, was identified in $76 \%$ of patients with DI and suspected infundibular LH, but is not widely available yet [92]. Serum anti-pituitary antibodies could however be useful in special cases, helping to avoid an underestimation of autoimmune hypophysitis; these cases include idiopathic hypopituitarism associated with other autoimmune diseases and hyperprolactinemia without pituitary adenoma on MRI or in empty sella syndrome [53].

\section{Conclusion}

Hypophysitis is a heterogenous condition with diverse etiologies, although most subtypes develop in the context of a strong autoimmune background. The recognition of new causes, such as IgG4-, anti-PIT-1-, and ICI-induced hypophysitis, as well as the improvement of imaging techniques have led to an increase in its incidence. Replacement of pituitary hormonal deficiencies is the sole medical treatment in most mild and/or chronic cases, but in severe acute presentations, presence of mass effects, and/or progressive/recurrent cases, treatment with glucocorticoids and/or other immunosuppressive agents is required. In cases of $\mathrm{SH}$, disease-specific treatment may also be needed. Although current biomarkers are not disease-specific, it is expected that serological markers such as HLA-DQ8/ HLA-DR53 and newer anti-pituitary antibodies will emerge as promising noninvasive diagnostic tools facilitating diagnosis and predicting prognosis and response to glucocorticoids and other evolving treatments.

\section{Disclosure Statement}

The authors have no conflicts of interest to declare.

\section{Funding Sources}

None.

\section{Author Contributions}

Conception and design: G. Kaltsas and E. Kassi. Literature search: A. Angelousi and M. Tsoli. Drafting of the article: G. Kaltsas, E. Kassi, and A. Angelousi. Critical revision of the article: G. Kaltsas, E. Kassi, and K. Alexandraki. 


\section{References}

1 Joshi MN, Whitelaw BC, Carroll PV. Mechanisms in endocrinology: hypophysitis: diagnosis and treatment. Eur J Endocrinol. 2018 Sep;179(3):R151-63.

2 Yuen KC, Popovic V, Trainer PJ. New causes of hypophysitis. Best Pract Res Clin Endocrinol Metab. 2019 Apr;33(2):101276.

3 Prete A, Salvatori R. Hypophysitis. Endotext [Internet]; 2000. Available from: https:// www.ncbi.nlm.nih.gov/books/NBK519842/.

4 Caturegli P, Newschaffer C, Olivi A, Pomper MG, Burger PC, Rose NR. Autoimmune hypophysitis. Endocr Rev. 2005 Aug;26(5):599_ 614.

5 Sautner D, Saeger W, Lüdecke DK, Jansen V, Puchner MJ. Hypophysitis in surgical and autoptical specimens. Acta Neuropathol. 1995;90(6):637-44.

6 Gubbi S, Hannah-Shmouni F, Verbalis JG, Koch CA. Hypophysitis: an update on the novel forms, diagnosis and management of disorders of pituitary inflammation. Best Pract Res Clin Endocrinol Metab. 2019 Dec; 33(6):101371.

7 Takahashi Y. Mechanisms in endocrinology: Autoimmune hypopituitarism: novel mechanistic insights. Eur J Endocrinol. 2020 Apr; 182(4):R59-66.

8 Imga NN, Yildirim AE, Baser OO, Berker D. Clinical and hormonal characteristics of patients with different types of hypophysitis: a single-center experience. Arch Endocrinol Metab. 2019 Feb;63(1):47-52.

9 Faje A. Hypophysitis: evaluation and management. Clin Diabetes Endocrinol. 2016 Sep; 2(1): 15 .

10 Ćaćić M, Marinković J, Kruljac I, Perić B, Čerina V, Stipić D, et al. Ischemic Pituitary Apoplexy, Hypopituitarism and Diabetes Insipidus: a Triad Unique to Necrotizing Hypophysitis. Acta Clin Croat. 2018 Dec;57(4): 768-71.

11 Lin W, Gao L, Guo X, Wang W, Xing B. Xanthomatous Hypophysitis Presenting with Diabetes Insipidus Completely Cured Through Transsphenoidal Surgery: Case Report and Literature Review. World Neurosurg. 2017 Aug;104:1051.e7-13.

12 Duan K, Asa SL, Winer D, Gelareh Z, Gentili F, Mete O. Xanthomatous Hypophysitis Is Associated with Ruptured Rathke's Cleft Cyst. Endocr Pathol. 2017 Mar;28(1):83-90.

13 Kleinschmidt-DeMasters BK, Lillehei KO, Hankinson TC. Review of xanthomatous lesions of the sella. Brain Pathol. 2017 May; 27(3):377-95

14 Chung CH, Song MS, Cho HD, Jeong S, Kim YJ, Bae HG, et al. A case of idiopathic granulomatous hypophysitis. Korean J Intern Med (Korean Assoc Intern Med). 2012 Sep;27(3): 346-9.

15 Hunn BH, Martin WG, Simpson S Jr, Mclean CA. Idiopathic granulomatous hypophysitis: a systematic review of 82 cases in the literature. Pituitary. 2014 Aug;17(4):357-65.
16 Guaraldi F, Giordano R, Grottoli S, Ghizzoni L, Arvat E, Ghigo E. Pituitary autoimmunity. Front Horm Res. 2017;48:48-68.

17 Caturegli P, Di Dalmazi G, Lombardi M, Grosso F, Larman HB, Larman T, et al. Hypophysitis Secondary to Cytotoxic T-Lymphocyte-Associated Protein 4 Blockade: Insights into Pathogenesis from an Autopsy Series. Am J Pathol. 2016 Dec;186(12):3225-35.

18 Makras P, Kaltsas G. Langerhans cell histiocytosis and pituitary function. Endocrine. 2015 Apr;48(3):728-9.

19 Imashuku S, Kudo N, Kaneda S, Kuroda H, Shiwa T, Hiraiwa T, et al. Treatment of patients with hypothalamic-pituitary lesions as adult-onset Langerhans cell histiocytosis. Int J Hematol. 2011 Dec;94(6):556-60.

20 Pekic S, Popovic V. Diagnosis of endocrine disease: expanding the cause of hypopituitarism. EurJEndocrinol.2017 Jun;176(6):R26982.

21 Huang YY, Lin SF, Dunn P, Wai YY, Hsueh C, Tsai JS. Primary pituitary lymphoma presenting as hypophysitis. Endocr J. 2005 Oct; 52(5):543-9.

22 Martinez JH, Davila Martinez M, Mercado de Gorgola M, Montalvo LF, Tome JE. The coexistence of an intrasellar adenoma, lymphocytic hypophysitis, and primary pituitary lymphoma in a patient with acromegaly. Case Rep Endocrinol. 2011;2011:941738.

23 León-Suárez A, Roldán-Sarmiento P, GómezSámano MA, Nava-De la Vega A, EnríquezEstrada VM, Gómez-Pérez FJ, et al. Infundibulo-hypophysitis-like radiological image in a patient with pituitary infiltration of a diffuse large B-cell non-Hodgkin lymphoma. Endocrinol Diabetes Metab Case Rep. 2016;2016: 16-0103.

24 Alves R, França M. Subacute hypophysitis with panhypopituitarism as first presentation of HIV and syphilis coinfection. Case Rep Infect Dis. 2017;2017:1489210.

25 Bernreuther C, Illies C, Flitsch J, Buchfelder M, Buslei R, Glatzel M, et al. IgG4-related hypophysitis is highly prevalent among cases of histologically confirmed hypophysitis. Brain Pathol. 2017 Nov;27(6):839-45.

26 Leporati P, Landek-Salgado MA, Lupi I, Chiovato L, Caturegli P. IgG4-related hypophysitis: a new addition to the hypophysitis spectrum. J Clin Endocrinol Metab. 2011 Jul; 96(7):1971-80.

27 Faje AT, Sullivan R, Lawrence D, Tritos NA, Fadden R, Klibanski A, et al. Ipilimumab-induced hypophysitis: a detailed longitudinal analysis in a large cohort of patients with metastatic melanoma. J Clin Endocrinol Metab. 2014 Nov;99(11):4078-85.

28 Araujo PB, Coelho MC, Arruda M, Gadelha MR, Neto LV. Ipilimumab-induced hypophysitis: review of the literature. J Endocrinol Invest. 2015 Nov;38(11):1159-66.
29 Barroso-Sousa R, Ott PA. PD-1 inhibitors in endometrial cancer. Oncotarget. 2017 Nov; 8(63):106169-70

30 Cukier P, Santini FC, Scaranti M, Hoff AO Endocrine side effects of cancer immunotherapy. Endocr Relat Cancer. 2017 Dec; 24(12):T331-47.

31 Larkin J, Chiarion-Sileni V, Gonzalez R, Grob JJ, Cowey CL, Lao CD, et al. Combined Nivolumab and Ipilimumab or Monotherapy in Untreated Melanoma. N Engl J Med. 2015 Jul;373(1):23-34.

32 Milne P, Bigley V, Bacon CM, Néel A, McGovern N, Bomken S, et al. Hematopoietic origin of Langerhans cell histiocytosis and Erdheim-Chester disease in adults. Blood. 2017 Jul;130(2):167-75.

33 Courtillot C, Laugier Robiolle S, Cohen Aubart F, Leban M, Renard-Penna R, Drier A, et al. Endocrine Manifestations in a Monocentric Cohort of 64 Patients With ErdheimChester Disease. J Clin Endocrinol Metab. 2016 Jan;101(1):305-13.

34 Yamamoto M, Iguchi G, Takeno R, Okimura Y, Sano T, Takahashi M, et al. Adult combined GH, prolactin, and TSH deficiency associated with circulating PIT-1 antibody in humans. J Clin Invest. 2011 Jan;121(1):1139.

35 Yamamoto M, Iguchi G, Bando H, Kanie K, Hidaka-Takeno R, Fukuoka H, et al. Autoimmune pituitary disease: new concepts with clinical implications. Endocr Rev. 2020 Apr; 41(2):bnz003

36 Raslan OA, Schellingerhout D, Fuller GN, Ketonen LM. Rosai-Dorfman disease in neuroradiology: imaging findings in a series of 10 patients. AJR Am J Roentgenol. 2011 Feb; 196(2):W187-93.

37 Świątkowska-Stodulska R, Stodulski D, Babińska A, Piskunowicz M, Sworczak K. Bilateral Tolosa-Hunt syndrome mimicking pituitary adenoma. Endocrine. 2017 Dec;58(3): 582-6.

38 Gutenberg A, Hans V, Puchner MJ, Kreutzer J, Brück W, Caturegli P, et al. Primary hypophysitis: clinical-pathological correlations. Eur J Endocrinol. 2006 Jul;155(1):101-7.

39 Rao S, Mahadevan A, Maiti T, Ranjan M, Shwetha SD, Arivazhagan A, et al. Granulomatous and lymphocytic hypophysitis - are they immunologically distinct? APMIS. 2016 Dec;124(12):1072-7.

40 Mirocha S, Elagin RB, Salamat S, Jaume JC. T regulatory cells distinguish two types of primary hypophysitis. Clin Exp Immunol. 2009 Mar;155(3):403-11.

41 Singh K, Kanodia AK, Ross P, Torgersen A, Maclean J, Leese G, et al. Xanthomatous hypophysitis causing hypogonadotropic hypogonadism resulting in delayed presentation of slipped capital femoral epiphysis. Br J Neurosurg. doi: 10.1080/02688697.2018.1525482 [Epub ahead of print]. 
42 Barroso-Sousa R, Barry WT, Garrido-Castro AC, Hodi FS, Min L, Krop IE, et al. Incidence of Endocrine Dysfunction Following the Use of Different Immune Checkpoint Inhibitor Regimens: A Systematic Review and Metaanalysis. JAMA Oncol. 2018 Feb;4(2):173-82.

43 Iwama S, De Remigis A, Callahan MK, Slovin SF, Wolchok JD, Caturegli P. Pituitary expression of CTLA-4 mediates hypophysitis secondary to administration of CTLA-4 blocking antibody. Sci Transl Med. 2014 Apr; 6(230):230ra45.

44 Angelousi A, Chatzellis E, Kaltsas G. New Molecular, Biological, and Immunological Agents Inducing Hypophysitis. Neuroendocrinology. 2018;106(1):89-100.

45 Kanie K, Bando H, Iguchi G, Muguruma K, Matsumoto R, Hidaka-Takeno R, et al. Pathogenesis of Anti-PIT-1 Antibody Syndrome: PIT-1 Presentation by HLA Class I on Anterior Pituitary Cells. J Endocr Soc. 2019 Aug; 3(11):1969-78.

46 Gutenberg A, Buslei R, Fahlbusch R, Buchfelder M, Brück W. Immunopathology of primary hypophysitis: implications for pathogenesis. Am J Surg Pathol. 2005 Mar;29(3): 329-38.

47 Hanna B, Li YM, Beutler T, Goyal P, Hall WA Xanthomatous hypophysitis. J Clin Neurosci. 2015 Jul;22(7):1091-7.

48 Park SM, Bae JC, Joung JY, Cho YY, Kim TH, Jin SM, et al. Clinical characteristics, management, and outcome of 22 cases of primary hypophysitis. Endocrinol Metab (Seoul). 2014 Dec;29(4):470-8

49 Gutenberg A, Caturegli P, Metz I, Martinez R, Mohr A, Brück W, et al. Necrotizing infundibulo-hypophysitis: an entity too rare to be true? Pituitary. 2012 Jun;15(2):202-8.

50 Pekic S, Bogosavljevic V, Peker S, Doknic M, Miljic D, Stojanovic M, et al. Lymphocytic hypophysitis successfully treated with stereotactic radiosurgery: case report and review of the literature. J Neurol Surg A Cent Eur Neurosurg. 2018 Jan;79(1):77-85.

51 Glezer A, Bronstein MD. Pituitary autoimmune disease: nuances in clinical presentation. Endocrine. 2012 Aug;42(1):74-9.

52 Angelousi A, Cohen C, Sosa S, Danilowicz K Papanastasiou L, Tsoli M, et al. Clinical, Endocrine and Imaging Characteristics of $\mathrm{Pa}$ tients with Primary Hypophysitis. Horm Metab Res. 2018 Apr;50(4):296-302.

53 Bellastella G, Maiorino MI, Bizzarro A, Giugliano D, Esposito $\mathrm{K}$, Bellastella $\mathrm{A}$, et al. Revisitation of autoimmune hypophysitis: knowledge and uncertainties on pathophysiological and clinical aspects. Pituitary. 2016 Dec;19(6):625-42.

54 Falorni A, Minarelli V, Bartoloni E, Alunno A, Gerli R. Diagnosis and classification of autoimmune hypophysitis. Autoimmun Rev. 2014 Apr-May;13(4-5):412-6.

55 Caturegli P, Lupi I, Landek-Salgado M, Kimura H, Rose NR. Pituitary autoimmunity: 30 years later. Autoimmun Rev. 2008 Sep;7(8): $631-7$.
56 Kong X, Wang R, Yang Y, Wu H, Su C, Ma W, et al. Idiopathic Granulomatous Hypophysitis Mimicking Pituitary Abscess. Medicine (Baltimore). 2015 Jul;94(28):e1099.

57 Aste L, Bellinzona M, Meleddu V, Farci G, Manieli C, Godano U. Xanthomatous hypophysitis mimicking a pituitary adenoma: case report and review of the literature. J Oncol. 2010;2010:195323.

58 Honegger J, Schlaffer S, Menzel C, Droste M, Werner S, Elbelt U, et al.; Pituitary Working Group of the German Society of Endocrinology. Diagnosis of Primary Hypophysitis in Germany. J Clin Endocrinol Metab. 2015 Oct 100(10):3841-9.

59 Wong S, Lam WY, Wong WK, Lee KC. Hypophysitis presented as inflammatory pseudotumor in immunoglobulin G4-related systemic disease. Hum Pathol. 2007 Nov;38(11): $1720-3$.

60 Iwata N, Iwama S, Sugimura Y, Yasuda Y, Nakashima K, Takeuchi S, et al. Anti-pituitary antibodies against corticotrophs in IgG4-related hypophysitis. Pituitary. 2017 Jun;20(3):301-10.

61 Shikuma J, Kan K, Ito R, Hara K, Sakai H, Miwa $\mathrm{T}$, et al. Critical review of IgG4-related hypophysitis. Pituitary. 2017 Apr;20(2):282-91.

62 Gu WJ, Zhang Q, Zhu J, Li J, Wei SH, Mu YM. Rituximab was used to treat recurrent IgG4related hypophysitis with ophthalmopathy as the initial presentation: A case report and literature review. Medicine (Baltimore). 2017 Jun;96(24):e6934

63 Dillard T, Yedinak CG, Alumkal J, Fleseriu M. Anti-CTLA-4 antibody therapy associated autoimmune hypophysitis: serious immune related adverse events across a spectrum of cancer subtypes. Pituitary. 2010;13(1):29-38.

64 Bertrand A, Kostine M, Barnetche T, Truchetet ME, Schaeverbeke T. Immune related adverse events associated with anti-CTLA-4 antibodies: systematic review and meta-analysis. BMC Med. 2015 Sep;13(1):211.

65 Kassi E, Angelousi A, Asonitis N, Diamantopoulos $P$, Anastasopoulou A, Papaxoinis G, et al. Endocrine-related adverse events associated with immune-checkpoint inhibitors in patients with melanoma. Cancer Med. 2019 Nov;8(15):6585-94.

66 Radojkovic D, Pesic M, Dimic D, Radjenovic Petkovic T, Radenkovic S, Velojic-Golubovic $\mathrm{M}$, et al. Localised Langerhans cell histiocytosis of the hypothalamic-pituitary region: case report and literature review. Hormones (Athens). 2018 Mar;17(1):119-25.

67 Prosch H, Grois N, Prayer D, Waldhauser F, Steiner M, Minkov M, et al. Central diabetes insipidus as presenting symptom of Langerhans cell histiocytosis. Pediatr Blood Cancer. 2004 Oct;43(5):594-9.

68 Allen CE, Ladisch S, McClain KL. How I treat Langerhans cell histiocytosis. Blood. $2015 \mathrm{Jul}$; 126(1):26-35.

69 Tanimoto K, Imbe A, Shishikura K, Imbe H, Hiraiwa T, Miyata T, et al. Reversible hypopituitarism with pituitary tuberculoma. Intern Med. 2015;54(10):1247-51.
70 Albarel F, Gaudy C, Castinetti F, Carré T, Morange I, Conte-Devolx B, et al. Long-term follow-up of ipilimumab-induced hypophysitis, a common adverse event of the anti-CTLA-4 antibody in melanoma. Eur J Endocrinol. 2015 Feb;172(2):195-204.

71 Caranci F, Leone G, Ponsiglione A, Muto M, Tortora F, Muto M, et al. Imaging findings in hypophysitis: a review. Radiol Med. 2020 Mar;125(3):319-28.

72 Gubbi S, Hannah-Shmouni F, Stratakis CA, Koch CA. Primary hypophysitis and other autoimmune disorders of the sellar and suprasellar regions. Rev Endocr Metab Disord. 2018 Dec;19(4):335-47.

73 Saiwai S, Inoue Y, Ishihara T, Matsumoto S, Nemoto Y, Tashiro T, et al. Lymphocytic adenohypophysitis: skull radiographs and MRI. Neuroradiology. 1998 Feb;40(2):114-20.

74 Gutenberg A, Larsen J, Lupi I, Rohde V, Caturegli P. A radiologic score to distinguish autoimmune hypophysitis from nonsecreting pituitary adenoma preoperatively. AJNR Am J Neuroradiol. 2009 Oct;30(9):1766-72.

75 Ray DK, Yen CP, Vance ML, Laws ER, Lopes B, Sheehan JP. Gamma knife surgery for lymphocytic hypophysitis. J Neurosurg. 2010 Jan; 112(1):118-21.

76 Lupi I, Cosottini M, Caturegli P, Manetti L, Urbani C, Cappellani D, et al. Diabetes insipidus is an unfavorable prognostic factor for response to glucocorticoids in patients with autoimmune hypophysitis. Eur J Endocrinol. 2017 Aug; 177(2):127-35.

77 Chiloiro S, Tartaglione T, Capoluongo ED, Angelini F, Arena V, Giampietro A, et al. Hypophysitis Outcome and Factors Predicting Responsiveness to Glucocorticoid Therapy: A Prospective and Double-Arm Study. J Clin Endocrinol Metab. 2018 Oct;103(10):3877-89.

78 Lupi I, Zhang J, Gutenberg A, Landek-Salgado M, Tzou SC, Mori S, et al. From pituitary expansion to empty sella: disease progression in a mouse model of autoimmune hypophysitis. Endocrinology. 2011 Nov;152(11):4190-8.

79 Schreckinger M, Francis T, Rajah G, Jagannathan J, Guthikonda M, Mittal S. Novel strategy to treat a case of recurrent lymphocytic hypophysitis using rituximab. J Neurosurg. 2012 Jun;116(6):1318-23.

80 De Bellis A, Colella C, Bellastella G, Savoia A, Guastafierro S, Cozzolino D, et al. Rituximabinduced remission of autoimmune hypophysitis and primary immune thrombocytopenia in a patient with autoimmune polyendocrine syndrome type 4. Expert Rev Endocrinol Metab. 2014 Jul;9(4):313-7.

81 Xu C, Ricciuti A, Caturegli P, Keene CD, Kargi AY. Autoimmune lymphocytic hypophysitis in association with autoimmune eye disease and sequential treatment with infliximab and rituximab. Pituitary. 2015 Aug; 18(4): 441-7.

82 Kalra AA, Riel-Romero RM, Gonzalez-Toledo E. Lymphocytic hypophysitis in children: a novel presentation and literature review. J Child Neurol. 2011 Jan;26(1):87-94. 
83 Gellner V, Kurschel S, Scarpatetti M, Mokry M. Lymphocytic hypophysitis in the pediatric population. Childs Nerv Syst. 2008 Jul;24(7): 785-92.

84 Sheehan JP, Niranjan A, Sheehan JM, Jane JA Ir, Laws ER, Kondziolka D, et al. Stereotactic radiosurgery for pituitary adenomas: an intermediate review of its safety, efficacy, and role in the neurosurgical treatment armamentarium. J Neurosurg. 2005 Apr;102(4):678-91.

85 Khosroshahi A, Wallace ZS, Crowe JL, Akamizu T, Azumi A, Carruthers MN, et al.; Second International Symposium on IgG4-Related Disease. International Consensus Guidance Statement on the Management and Treatment of IgG4-Related Disease. Arthritis Rheumatol. 2015 Jul;67(7):1688-99.

86 Sasaki Yatabe M, Watanabe K, Hayashi Y, Yatabe J, Morimoto S, Ichihara A, et al. Overlap of Post-obstructive Diuresis and Unmasked Diabetes Insipidus in a Case of IgG4-related Retroperitoneal Fibrosis and Tuberoinfundibular Hypophysitis: A Case Report and Review of the Literature. Intern Med. 2017; 56(1):47-53.
87 Grois N, Fahrner B, Arceci RJ, Henter JI, McClain K, Lassmann H, et al.; Histiocyte Society CNS LCH Study Group. Central nervous system disease in Langerhans cell histiocytosis. J Pediatr. 2010 Jun;156(6):873-881.e1.

88 Haroche J, Cohen-Aubart F, Emile JF, Arnaud L, Maksud P, Charlotte F, et al. Dramatic efficacy of vemurafenib in both multisystemic and refractory Erdheim-Chester disease and Langerhans cell histiocytosis harboring the BRAF V600E mutation. Blood. 2013 Feb;121(9):1495-500.

89 Anthony J, Esper GJ, Ioachimescu A. Hypothalamic-pituitary sarcoidosis with vision loss and hypopituitarism: case series and literature review. Pituitary. 2016 Feb;19(1):19-29.

90 Vega-Beyhart A, Medina-Rangel IR, Hinojosa-Azaola A, Fernández-Barrio $\mathrm{M}$, VargasCastro AS, García-Inciarte L, et al. Pituitary dysfunction in granulomatosis with polyangiitis. Clin Rheumatol. 2020 Feb;39(2):595606.
91 Heaney AP, Sumerel B, Rajalingam R, Bergsneider M, Yong WH, Liau LM. HLA Markers DQ8 and DR53 Are Associated With Lymphocytic Hypophysitis and May Aid in Differential Diagnosis. J Clin Endocrinol Metab. 2015 Nov; 100(11):4092-7.

92 Iwama S, Sugimura Y, Kiyota A, Kato T, Enomoto A, Suzuki H, et al. Rabphilin-3A as a Targeted Autoantigen in Lymphocytic Infundibulo-neurohypophysitis. J Clin Endocrinol Metab. 2015 Jul;100(7):E946-54.

93 Bando H, Iguchi G, Fukuoka H, Taniguchi M, Yamamoto M, Matsumoto R, et al. The prevalence of IgG4-related hypophysitis in 170 consecutive patients with hypopituitarism and/or central diabetes insipidus and review of the literature. Eur J Endocrinol. 2013 Dec; 170(2):161-72.

94 Lee J, Hyun SH, Kim S, Kim DK, Lee JK, Moon SH, et al. Utility of FDG PET/CT for Differential Diagnosis of Patients Clinically Suspected of IgG4-Related Disease. Clin Nucl Med. 2016 May;41(5):e237-43. 